\title{
EFEKTIFITAS PERATURAN DAERAH KOTA TANJUNGPINANG NOMOR 7 TAHUN 2010 TENTANG BANGUNAN GEDUNG TERKAIT PENERBITAN IZIN MENDIRIKAN BANGUNAN RUMAH TINGGAL DI KOTA TANJUNGPINANG
}

\author{
Agus haryono* \\ Dinas Penanaman Modal Pelayanan Terpadu \\ Satu Pintu (DPMPTSP ) Kota Tanjungpinang
}

\begin{abstract}
Residential Building is a part of the basic need for humans to carry out their activities. The developments in each region are rapidly growing. The problems that arise from construction activities are when they are not in accordance with their functions and spatial plans. Accordingly, the Tanjungpinang city government issued a regulation of the Tanjungpinang City Regional Regulation Number 7 of 2010 concerning Building. The objectives of the study is to evaluate whether the buildings in Tanjungpinang City have met the requirements and they are in accordance with the functions and spatial planning. It also analizes the legal certainty in the implementation of the building permit in this city.
\end{abstract}

Keywords: Effectiveness, building permit, Tanjungpinang City.

\begin{abstract}
Abstrak
Bangunan Rumah Tinggal adalah merupakan bagian kebutuhan primer/mendasar manusia dalam melakukan kegiatannya. Perkembangan pembangunan di tiap wilayah kian bertambah pesat. Permasalahan yang timbul dari pembangunan konstruksi ketika konstruksi tidak sesuai dengan fungsi dan tata ruangnya. Oleh karena itu, Pemerintah Kota Tanjungpinang mengeluarkan peraturan yang tertuang dalam Peraturan Daerah Kota Tanjungpinang Nomor 7 Tahun 2010 tentang Bangunan Gedung. Tujuan dari penelitian ini untuk mengevaluasi apakah bangunan gedung di Kota Tanjungpinang telah memenuhi syarat administratif dan teknis bangunan gedung sesuai dengan fungsi dan tata ruang serta menganalisis kepastian hukum dalam penyelenggaraan Izin Mendirikan Bangunan di kota tersebut.

Kata kunci : Efektifitas, Izin Mendirikan Bangunan, Kota Tanjungpinang.

\section{A. Latar Belakang Masalah}

Dalam rangka mewujudkan tertib pembangunan, terutama terkait dengan bangunan gedung secara nasional, maka pemerintah mengeluarkan Undang-Undang Republik Indonesia Nomor 28 Tahun 2002 tentang Bangunan Gedung.Kemudian sebagai peraturan pelaksananya diterbitkan Peraturan Pemerintah Nomor 36 Tahun 2005
\end{abstract}

\footnotetext{
*Alamat korespondensi : agusharyonopcn@gmail.com
} 
mengenai Izin Mendirikan Bangunan. Untuk melaksanakan hal tersebut maka secara teknisnya pemerintah kota Tanjungpinang, mengeluarkan peraturan tentang bangunan gedung yang tertuang dalam Peraturan Daerah Kota Tanjungpinang Nomor 7 Tahun 2010. Adapun diuraikan lebih tegas tujuan Pemerintah mengeluarkan peraturan ini adalah untuk :

- Mewujudkan bangunan gedung yang memenuhi persyaratan administratif dan persyaratan teknis bangunan gedung sesuai dengan fungsi dan tata ruang, yang selaras dengan lingkungannya dan diselenggarakan dengan tertib untuk menjamin keandalan tehnis bangunan gedung ${ }^{1}$.

- Mewujudkan kepastian hukum dalam penyelenggaraan Izin Mendirikan Bangunan sehingga legalitas terhadap bangunan yang ada dapat terjamin dan dipertanggung jawabkan.

Penduduk Kota Tanjungpinang berkisar 263.000 jiwa dan $70.560 \mathrm{kk}$ dengan luas wilayah : $258.82 \mathrm{KM}^{2}$ yang terbagi menjadi 4 Kecamatan ${ }^{2}$. Kegiatan pembangunan rumah tinggal di empat Kecamatan tersebut banyak yang tidak memenuhi standard. Kurangnya penataan dan ketegasan pemerintah serta lemahnya kesadaran masyarakat dalam mentaati aturan dan kepengurusan Izin Mendirikan Bangunan. Menurut data pada DPMPTSP bahwa jumlah Izin Mendirikan Bangunan yang terdata dari Oktober 2009 hingga Desember 2017 adalah 1880 berkas. Jumlah total 1880 berkas tersebut terdiri dari ; Rumah tinggal 405 berkas (1.011 unit), perumahan 131 berkas (10.819 unit ), kios 35 berkas (309 unit), pertokoan 204 berkas (1285 unit), rumah kos 14 berkas (40 unit), Ruko 35 berkas ( 108 unit ), sekolah, tempat ibadah, , gudang dan sebagainya ${ }^{3}$.

Dengan melihat kenyataan bahwa kepemilikan Izin Mendirikan Bangunan bagi masyarakat yang sangat rendah terutama perumahan/rumah tinggal dan tidak sepadan dengan banyaknya jumlah bangunan perumahan yang ada pada masyarakat Kota Tanjungpinang, maka peneliti tertarik untuk menuangkannya dalam bentuk penelitian yang berjudul "EFEKTIVITAS PERATURAN DAERAH KOTA TANJUNGPINANG NOMOR 7 TAHUN 2010 TENTANG BANGUNAN GEDUNG TERKAIT PENERBITAN IZIN MENDIRIKAN BANGUNAN RUMAH TINGGAL DI KOTA TANJUNGPINANG".

\section{B. Perumusan masalah}

1. Bagaimana efektivitas Peraturan Daerah Nomor 7 Tahun 2010 tentang Bangunan Gedung terkait penerbitan Izin Mendirikan Bangunan Rumah Tinggal di Kota Tanjungpinang?

\footnotetext{
${ }^{1}$ Pasal 6 Bagian (1) dan Pasal 10 Bagian (2) Bab III, Peraturan Daerah Kota Tanjungpinang Nomor 7 Tahun 2010 Tentang Bangunan Gedung.

${ }^{2}$ Data Badan Pusat Statistik Kota Tanjungpinang Tahun 2017.

${ }^{3}$ Data DPMPTSP Kota Tanjungpinang 2017.
} 
2. Apa kendalanya dalam upaya untuk mengefektifkan Peraturan Derah Nomor 7 tahun 2010 tentang bangunan gedung terkait penerbitan izin mendirikan bangunan Rumah Tinggal di Kota Tanjungpinang?

3. Bagaimana solusi untuk mengatasi kendala tersebut agar Peraturan Daerah Nomor 7 tahun 2010 tentang bangunan gedung terkait penerbitan izin mendirikan bangunan Rumah Tinggal di Kota Tanjungpinang dapat berjalan secara efektif?

\section{Metode Penelitian}

Peneliti menggunakan penelitian hukum empiris/sosiologis. Metode penelitian hukum empiris adalah suatu metode penelitian hukum yang berfungsi untuk melihat hukum dalam arti nyata dan meneliti bagaimana bekerjanya hukum dilingkungan masyarakat. Dapat dikatakan bahwa penelitian hukum empiris merupakan suatu penelitian yang dilakukan di masyarakat dengan maksud dan tujuan untuk menemukan fakta yang ada, kemudian diteruskan dengan menemukan masalah, identifikasi masalah, dan mencari penyelesaian masalah sebagai solusi.

Penelitian hukum empiris menurut Soerjono Soekanto meliputi penelitian terhadap identifikasi hukum (hukum tidak tertulis) dan penelitian terhadap efektivitas hukum.Jenis penelitian hukum empiris yang di gunakan dalam penelitian ini adalah penelitian efektivitas hukum, yaitu efektivitas Peraturan Daerah Kota Tanjungpinang Nomor 7 Tahun 2010 tentang Bangunan Gedung Terkait Izin Mendirikan Bangunan Rumah Tinggal.

Untuk menjawab permasalahan dalam penelitian ini, maka obyek penelitian nya adalah :

1. Penelitian pada masyarakat yang ada pada rumah tinggal dan di perumahan yang telah memiliki IMB dan yang belum ada IMB.

2. Penelitian pada Dinas Penanaman Modal dan Pelayanan Terpadu Satu Pintu,Dinas PU dan Tata Ruang, Dinas Lingkungan Hidup dan Kantor SATPOL PP .

Berkenaan dengan penelitian ini adalah penelitian hukum empiris, maka data yang digunakan adalah data primer dan data sekunder. ${ }^{4}$ Data primer diperoleh dari hasil wawancara dan observasi, sedangkan data sekunder diperoleh dari bahan-bahan hukum primer dan sekunder.

Dalam melakukan analisis dan pengolahan data pada penelitian hukum empiris ini, peneliti mengacu pada cara analisis data ilmu social dan tergantung pada sifat data yang dikumpulkan oleh peneliti (tahap pengumpulan data), sedangkan metode yang digunakan adalah metode dengan pendekatan kualitatif, yaitu suatu metode yang dilakukan dengan cara memadukan antara penelitian kepustakaan dengan penelitian lapangan. Kumpulan data yang didapat dianalisis secara yuridis kualitatif dengan menggunakan metode berpikir deduktif (umum-khusus), yakni dengan menjabarkan,

${ }^{4}$ Soerjono dan Abdurrahman, Metode Penelitian; Suatu Pemikiran dan Penerapan, Jakarta : Rineka Cipta, 2005, Cet 2, hlm 56. 
mengkonstruksikan dan menafsirkan data yang didapat berdasarkan kaidah-kaidah, teori-teori, pengertian-pengertian hukum dan doktrin yang ada dalam dokumen, peraturan perundang-undangan, untuk menjawab permasalahan dalam penelitian. Analisis permasalahan penelitian di lapangan yakni mengenai penyelenggaraan bangunan gedung terkait Izin Mendirikan Bangunan Rumah tinggal, kemudian dikaji dan dikaitkan dengan peraturan-peraturan tentang Bangunan Gedung. Penyelenggaraan bangunan Rumah tinggal tersebut di analisa tentang kesesuaian antara aturan-aturan dengan kondisi yang sebenarnya, ada yang melanggar atau tidak, dan bagaimana mencari jalan keluar terhadap masalah yang ada.

Selanjutnya setelah selesai melakukan analisis, maka dilakukan pengkajian secara narasi deskriptif, yaitu menguraikan temuan di lapangan, yang selanjutnya ditarik suatu kesimpulan yang menjadi jawaban atas permasalahan yang diangkat dalam penelitian.

\section{Hasil Penelitian dan Pembahasan}

Efektifitas Peraturan Daerah Kota Tanjungpinang Nomor 7 Tahun 2010 Tentang Bangunan Gedung terkait Penertiban Izin Mendirikan Bangunan Rumah Tinggal dapat di tinjau melalui teori efektifitas hukum menurut Soerjono Soekanto, bahwa efektif atau tidaknya suatu hukum ditentukan oleh lima faktor yaitu :

1. Faktor hukumnya sendiri

Hukum mempunyai fungsi untuk kemanfaatan, kepastian dan keadilan. Namun terkadang dalam prakteknya di lapangan sering terjadi pertentangan antara kepastian hukum dan keadilan. Kepastian hukum bersifat kongkrit dan nyata sementara keadilan bersifat abstrak sehingga ketika seorang hakum memutuskan suatu perkara melalui penerapan Undang- Undang saja ada kalanya nilai keadilan itu tidak tercapai. Untuk itu jika melihat suatu permasalahan hukum setidaknya keadilan menjadi prioritas, karena hukum tidaklah semata-mata dilihat dari hukum tertulis saja, sebaliknya jika hukum tujuannya sekedar keadilan, maka kesulitannya karena keadilan itu bersifat subyektif, jadi permasalahannya sangat tergantung pada nilai-nilai intrinsik subyektif dari masing-masing orang.

2. Faktor penegak hukum

Dalam hal menjalankan tata kehidupan bermasyarakat, berbangsa dan bernegara, hukum adalah merupakan panglima. Hukum akan mengatur sesuai dengan tatanan yang sudah disepakati bersama. Selanjutnya sebagai perpanjangan tangan pemerintah, Aparatur adalah merupakan faktor penegak hukum yang mampu memberikan kepastian, keadilan dan kemanfaatan hukum secara proporsional. Aparatur penegak hukum adalah intitusi penegak hukum dan aparat/orang penegak hukum, diantaranya adalah kepolisian, kejaksaan,kehakiman, penasehat hukum dan petugas sipir lembaga pemasyarakatan. Setiap aparat dan aparatur mempunyai tugas dan 
kewenangan dan menjalankan fungsinya, diantaranya adalah tugas penerimaan laporan,peyelidikan, penyidikan, penuntutan, pembuktian, vonis dan pemberian sangsi dan upaya pembinaan terpidana.

Ada tiga hal penting yang mempengaruhi mekanisme bekerjanya aparat dan aparatur penegak hukum yakni : (1).Institusi penegak hukum beserta sarana dan prasarana pendukung dan mekanisme kerja kelembagaan; (2).Budaya kerja terkait aparatnya, termasuk terkait kesejahteraan aparatnya; (3).Perangkat peraturan yang mendukung kinerja kelembagaan maupun yang mengatur materi hukum yang dijadikan standar kerja.

3. Faktor sarana yang mendukung penegakan hukum.

Faktor pendukungnya diantaranya adalah sarana fisik dan sumber daya manusia yang handal, organisasi yang baik, peralatan yang memadai dan keuangan yang cukup.

4. Faktor masyarakat

Masyarakat mempuyai peran yang sangat besar terkait dengan efektivitas hukum. Penegakan hukum bermula dari masyarakat dan memberikan kedamaian untuk masyarakat. Jadi peran serta masyarakat sangat dibutuhkan.

5. Faktor budaya

Sebagai hasil karya, cipta dan rasa yang didasarkan pada karsa manusia didalam pergaulan hidup. Inti dari kebudayaan adalah nilai - nilai, norma, adat istiadat, kebiasaan yang berlaku dalam lingkungan sosial yang ada yang menjadi budaya hukum.

Dalam menerapkan Perda nomor 7 tahun 2010 tersebut maka pemerintah selaku pemegang kekuasaan harus memiliki rasa pengabdian dan kepedulian yang tinggi terhadap kepentingan masyarakat. Untuk itu Pemerintah harus melaksanakan perannya sebagai berikut ;

1. Sebagai regulator yaitu; Membuat aturan dan kebijakan-kebijakan yang terkait dengan bangunan rumah tinggal. Selain Perda nomor 7 Tahun 2010 yaitu Perda no.7 tahun 2012 tentang Retribusi, dan Perda no,10 Tahun 2014 tentang Tata Ruang Wilayah.

2. Sebagai motivator yaitu; memberikan motivasi, menggerakkan dan mendorong masyarakat agar dalam mendirikan rumah tinggal dapat mentaati aturan hukum yang berlaku.

3. Sebagai penegak hukum yaitu; Memberikan sosialisasi dan pemahaman kepada masyarakat terkait Perda bangunan gedung, melaksanakan pengawasan, penertiban dan penindakan pelanggaran bagi masyarakat yang menyelenggarakan pembangunan rumah tinggal tanpa izin. 
Adapun Intansi yang berperan penting dalam penerapan Peraturan Daerah Kota Tanjungpinang Nomor 7 Tahun 2010 tentang Bangunan Gedung terkait Izin Mendirikan Bangunan Rumah Tinggal adalah ;

1. Dinas Pekerjaan Umum dan Tata Ruang yaitu memberikan peran dalam rekomendasi tata ruang dan rencana teknis terkait izin mendirikan bangunan, terkait kesesuaian tata ruangnya, Garis sempadan bangunan, KDB, KLB. Hal ini sesuai dengan tugas pokok dan fungsinya Dinas PU dan Tata Ruang Kota Tanjungpinang yakni ;

1) Bidang tata ruang mempunyai tugas melaksanakan penyiapan perumusan dan pelaksanaan pengaturan, perencanaan tata ruang, pemanfaatan ruang dan pengendalian tata ruang sesuai dengan kewenangan Pemerintah Kota berdasarkan Peraturan Perundang-undangan yang berlaku.

2) Untuk melaksanakan tugas pokok sebagaimana dimaksud pada ayat (1), bidang tata ruang menyelenggarakan fungsi ;

a. Perumusan dan pelaksanaan kebijakan teknis bidang pengaturan penataan ruang Daerah Kota;

b. Perumusan dan pelaksanaan kebijakan teknis bidang perencanaan tata ruang wilayah kota dan kawasan strategis kota;

c. Perumusan dan pelaksanaan pemanfaatan ruang wilayah kota dan kawasan strategis kota;

d. Perumusan dan pelaksanaan pembinaan penataan ruang kepada masyarakat;

e. Melaksanakan pemberian izin rekomendasi pemanfaatan ruang (Advice Planning) serta pemberian rekomendasi teknis bangunan dalam pemberian izin mendirikan bangunan.

2. Dinas Lingkungan Hidup

Dinas Lingkungan Hidup mempunyai wewenang terkait pemberian rekomendasi dokumen lingkungan. Sebelum izin mendirikan bangunan rumah tinggal diterbitkan, kelayakan dan kesesuaian terkait sanitasi, pengairan air bersih maupun drainase, kecukupan ruang terbuka hijau dan dampak lain terhadap lingkungan harus di penuhi terlebih dahulu. Hal inilah peran penting DLH termasuk pengawasannya dalam penerapan Perda Bangunan Gedung.

3. Dinas Penanaman Modal Dan Pelayanan Terpadu Satu Pintu

Dinas ini mempunyai wewenang dalam menerbitkan izin mendirikan bangunan setelah adanya persyaratan-persyaratan yang cukup baik secara administrasi maupun secara teknis. Persyaratan teknis dipenuhi melalui rekomendasi-rekomendasi dinas teknis terkait, kemudian jika berkas persyaratan dirasa cukup lengkap maka Dinas PMPTSP memproses dan menerbitkan IMBnya. Adapun lebih jelasnya terkait tupoksi DPMPTSP dapat dilihat pada Peraturan Walikota Tanjungpinang Nomor 40 Tahun 2016 
Tentang Uraian Tugas Pokok Dan Fungsi Organisasi Dan Tata Kerja DPMPTSP pasal 17 diantaranya adalah menyelenggarakan fungsi :

-.Melaksanakan, merencanakan, mengolah, memeriksa, mengkoordinasi, memvalidasi, mengevaluasi, memimpin, pelaporan, mengadministrasi pelayanan, menerbitkan perizinan dan non perizinan $\mathrm{A}, \mathrm{B}$ dan $\mathrm{C}$.

4. Satuan Polisi Pamong Praja

Satuan ini mempuyai wewenang sebagai penegak Perda yang ada di Kota Tanjungpinang termasuk diantaranya Perda Bangunan Gedung.

Dari uraian tupoksi tersebut diatas maka secara umum dapat dikatakan peran Dinas PU dan Tata Ruang dan Dinas Lingkungan Hidup terkait penerapan Perda nomor 7 Tahun 2010 tentang Bangunan Gedung sangat penting dan strategis yaitu melaksanakan pemberian izin rekomendasi pemanfaatan ruang ( Advice Planning ) serta pemberian rekomendasi teknis bangunan dalam pemberian izin mendirikan bangunan, serta penataan lingkungan, hal ini akan dapat mendorong, mengatur dan menata proses penyelenggaraan izin mendirikan bangunan oleh masyarakat. Demikian halnya dengan peran DPMPTSP yang mempunyai kewenangan dalam menerbitkan IMB. Terkait kewenangannya tersebut DPMPTSP juga punya kewajiban memberikan sosialisasi kemasyarakat akan pentingnya pelaksanaan Perda Nomor 7 Tahun 2010 tentang Bangunan Gedung terkait Izin Mendirikan Bangunan Rumah Tinggal. Hal yang lebih penting adalah Peran Satpol PP sebagai penegak Perda harus dapat menegakkan aturan dengan benar dan tegas.

Adapun hasil Penelitian dilapangan terhadap efektifitas Peraturan Daerah Kota Tanjungpinang Nomor 7 Tahun 2010 tentang bangunan rumah tinggal mengambil 6 sampel sebagai berikut :

\section{Hasil Observasi}

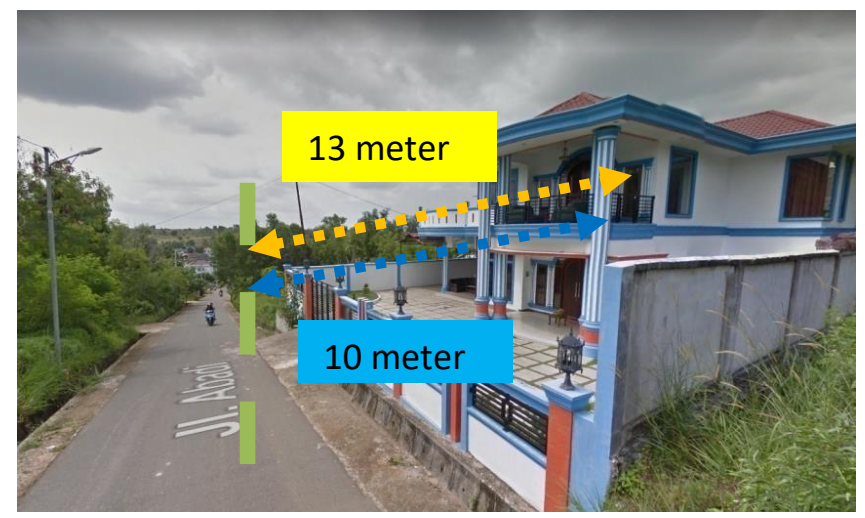

Gambar .4.1. Hasil Observasi 1 (Pembangunan Rumah Tinggal An. Syahrul Effendy) 


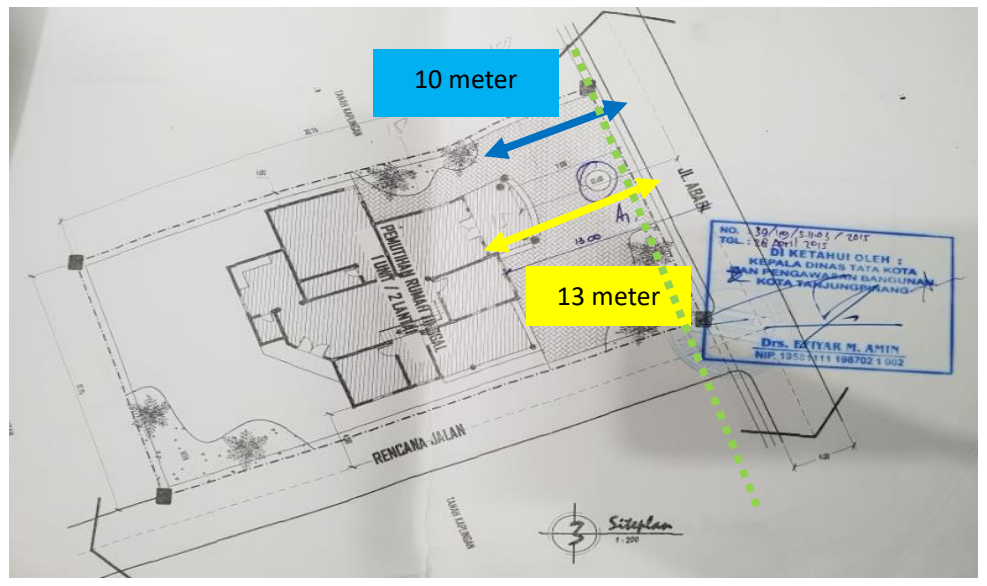

Gambar .4.2. Hasil Observasi 2 (Pembangunan Rumah Tinggal an. Syahrul Effendy)

Gambar tersebut diambil pada tanggal 15 Desember 2017 di Jl. Abadi Kota Tanjungpinang. Gambar 4.1 merupakan Gambar dimana lokasi bangunan pembangunan rumah tinggal diukur Garis Sempadan Bangunan (GSB) dari as jalan Abadi dengan pondasi rumah terdepan. Pada Gambar 4.2 Siteplan Pembangunan Rumah Tinggal an. Syahrul Effendy Garis Sempadan Bangunan (GSB) yang tertera yaitu 10 meter (bagian berwarna biru). Sedangkan batasan Garis Sempadan Bangunan (GSB) yang tertera di REKTIS adalah 13 meter (bagian berwarna kuning).

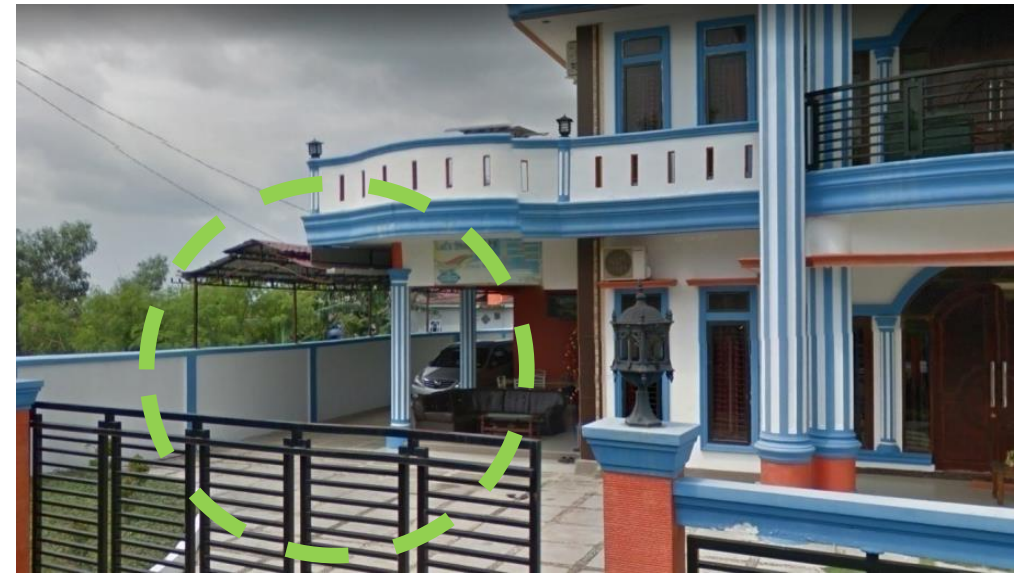

Gambar .4.3. Hasil Observasi 3 (Pembangunan Rumah Tinggal An. Syahrul Effendy) 


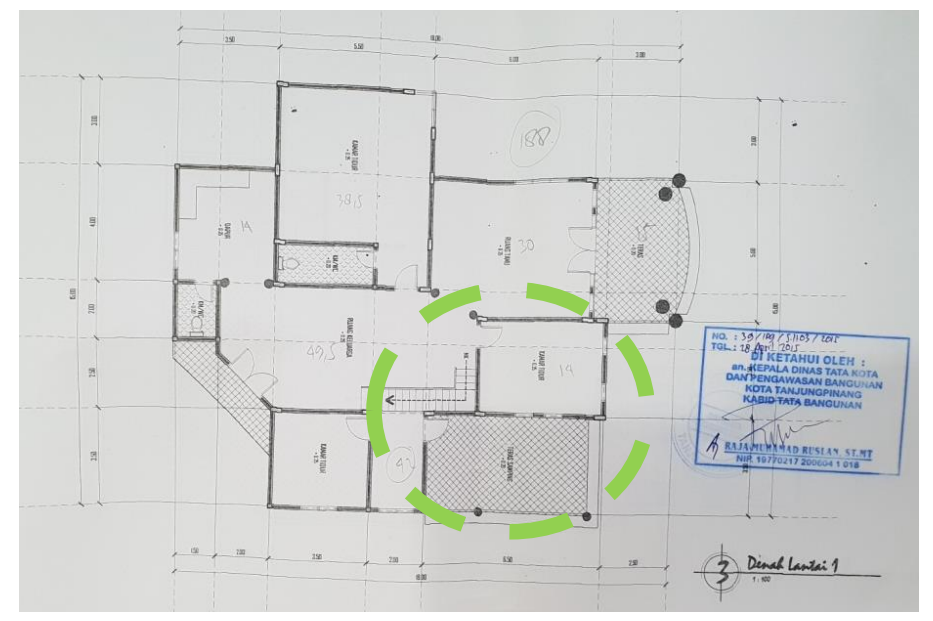

Gambar.4.4. Hasil Observasi 4 (Pembangunan Rumah Tinggal An. Syahrul Effendy)

Gambar 4.3 merupakan bentuk bangunan yang ditambah oleh pemilik bangunan yang tidak sesuai dengan IMB awal yang telah diterbitkan dari DPMPTSP. Pada gambar 4.4 denah lantai 1 bangunan rumah tinggal tidak terdapat garasi pada sisi kanan bangunan, sedangkan ketika peneliti mendatangi rumah tersebut terdapat penambahan bangunan.

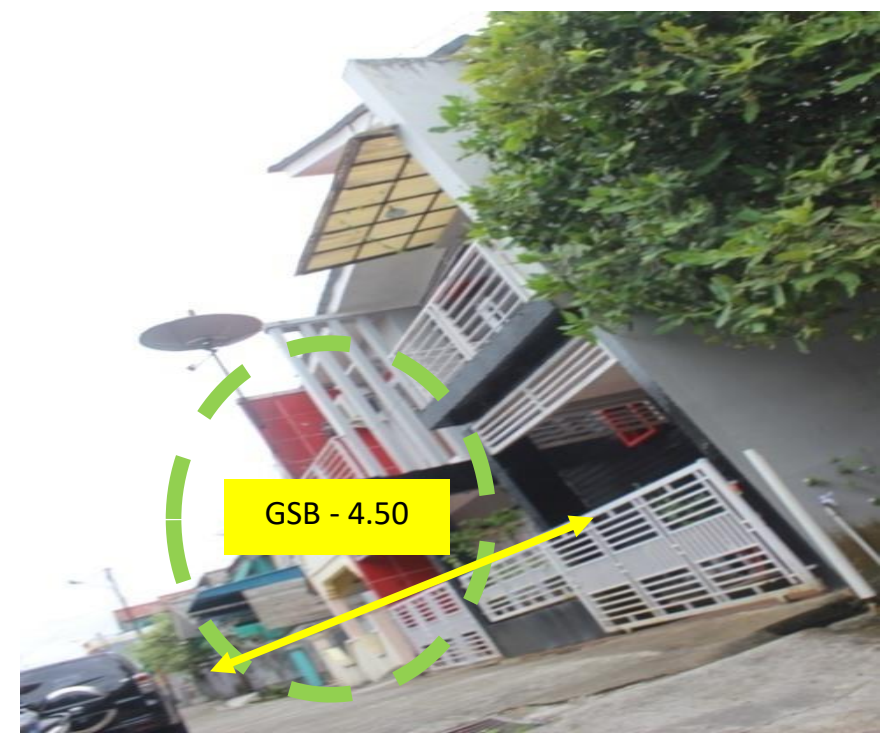

Gambar 4.5. Hasil Observasi 5 (Pemutihan Rumah Tinggal an. Benny Haryadisyah Putra) 
Gambar tersebut diambil pada tanggal 5 Desember 2017. Gambar 4.5 merupakan bentuk bangunan pemutihan rumah tinggal yang dimana luas seluruh lantainya melebihi dari batasan yang telah direkomendasikan. Garis Sempadan Bangunan Depan dari as jalan hingga pondasi terluar hanya 4,50 $\mathrm{m}$, sedangkan batasannya $6,00 \mathrm{~m}$. KDH yang seharusnya $10 \%$ hanya dapat dibangun $4.50 \%$ karena seluruh lantai bangunan sudah dibangun, sehingga akan mengurangi resapan air dan area peneduh.

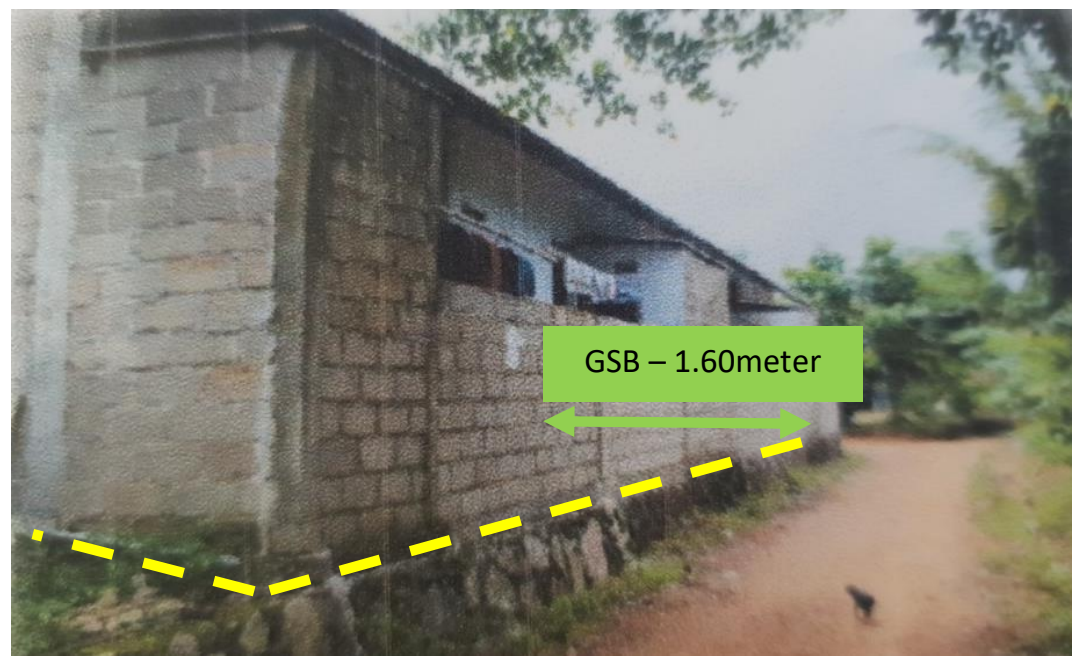

\section{Gambar 4.6. Hasil Observasi 6 (Pemutihan Rumah Tinggal dan Rumah Deret an. Sumini)}

Gambar tersebut diambil pada tanggal 6 Desember 2017. Gambar 4.6 menunjukan bangunan pemutihan rumah deret dibangun hingga kebatas tanah yang berbatasan dengan jalan sehingga jarak/Garis Sempadan Bangunan (GSB) yang ada hanya 1,60 meter dari batasan yang direkomendasikan 4,00 meter. Mereka menganggap bahwa tanah yang mereka miliki dan kuasai dianggap dapat dibangun seluruhnya sesuai dengan kehendaknya, tanpa memperhatikan estetika bangunan dan kepentingan umum, pada hal ada tata aturan atau kaidah terkait pembangunan yang telah ditetapkan oleh Pemerintah. Hal seperti inilah yang banyak dilakukan masyarakat, termasuk $\mathrm{Bu}$ Sumini, sehingga jika suatu saat ada pelebaran jalan maka akan menimbulkan suatu persoalan. 


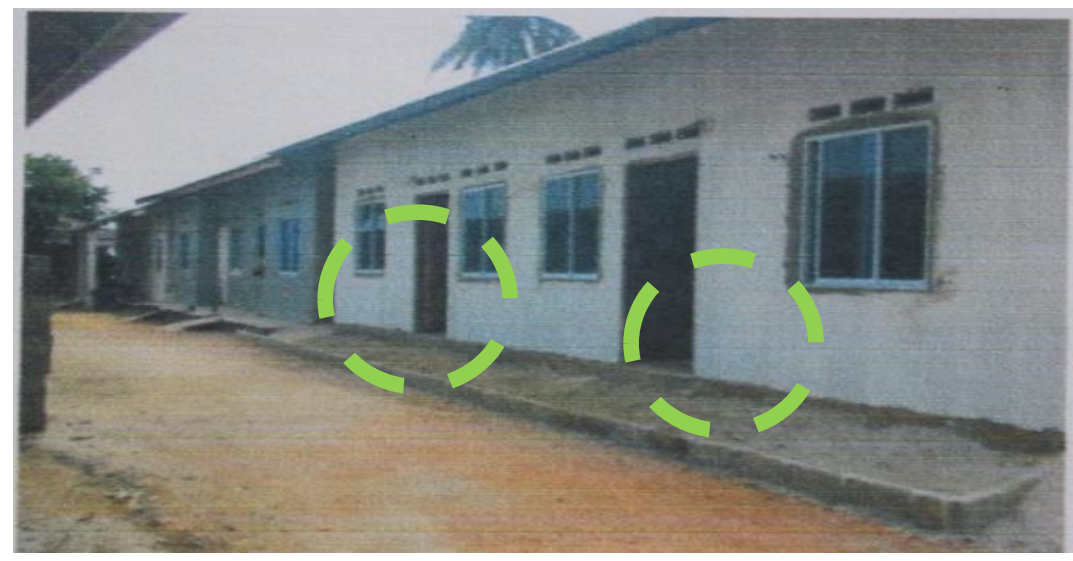

Gambar 4.7. Hasil Observasi 7 (Pemutihan Rumah Tinggal dan Rumah Deret an. Sumini)

Gambar 4.7 menunjukan bangunan pemutihan rumah deret tidak memiliki Ruang Terbuka Hijau yang seharusnya minimal $10 \%$ dari luas lahan. Namun kenyataan dilapangan /didepan rumahnya hanya terdapat tanah kosong disisi luar bangunan yang telah dicor dengan semen dan langsung berbatasan dengan lorong/gang.

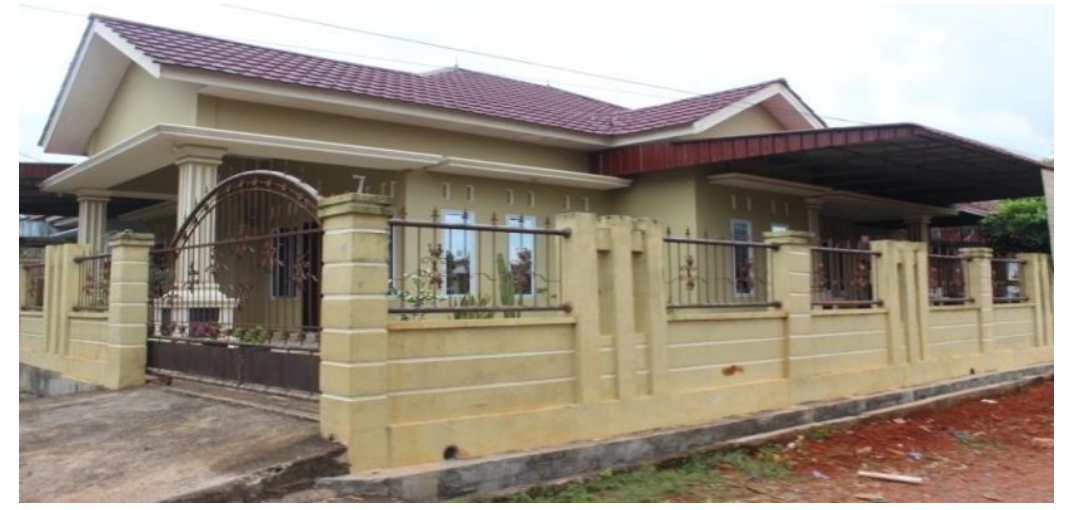

Gambar .4.8. Hasil Observasi 8 (Pemutihan Rumah Tinggal an. Corina Susantie)

Gambar tersebut diambil pada tanggal 6 Desember 2017 di Jalan Bukit Galang II Kota Tanjungpinang. Gambar 4.8 merupakan kondisi saat ini dilapangan bangunan pemutihan rumah tinggal yang dimana bentuk tanahnya memanjang kearah belakang namun tidak sesuai dengan sertifikat tanah. 

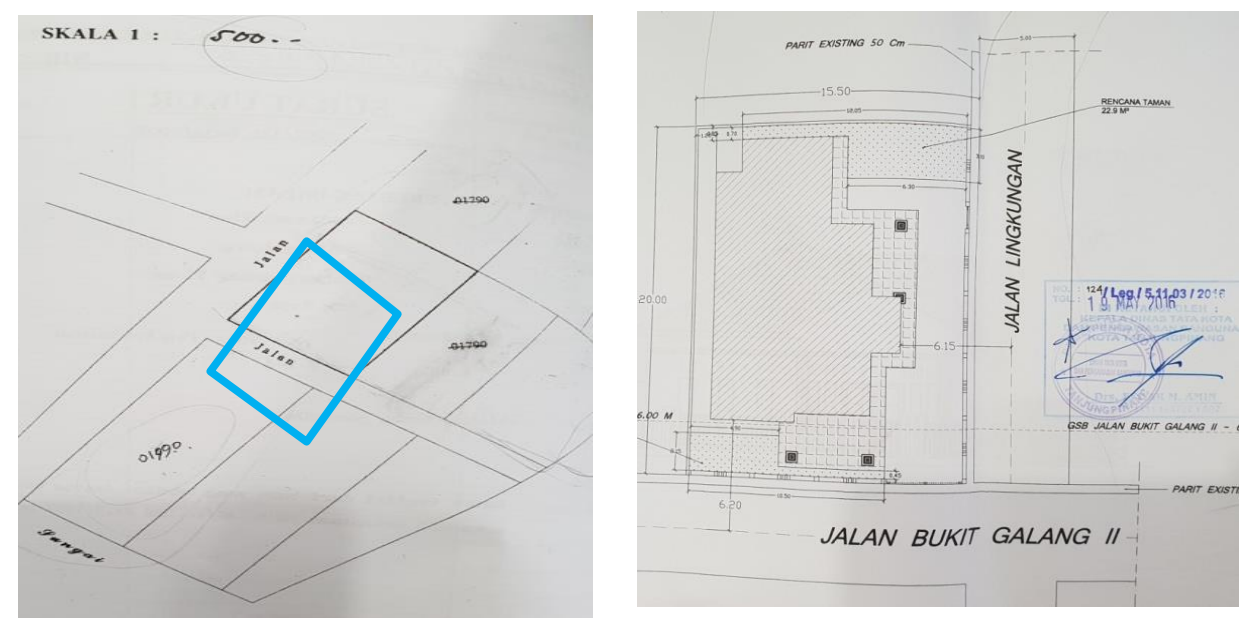

Gambar .4.9. Hasil Observasi 8 (Gambar Sertifikat dan Siteplan Pemutihan Rumah Tinggal an. Corina Susantie)

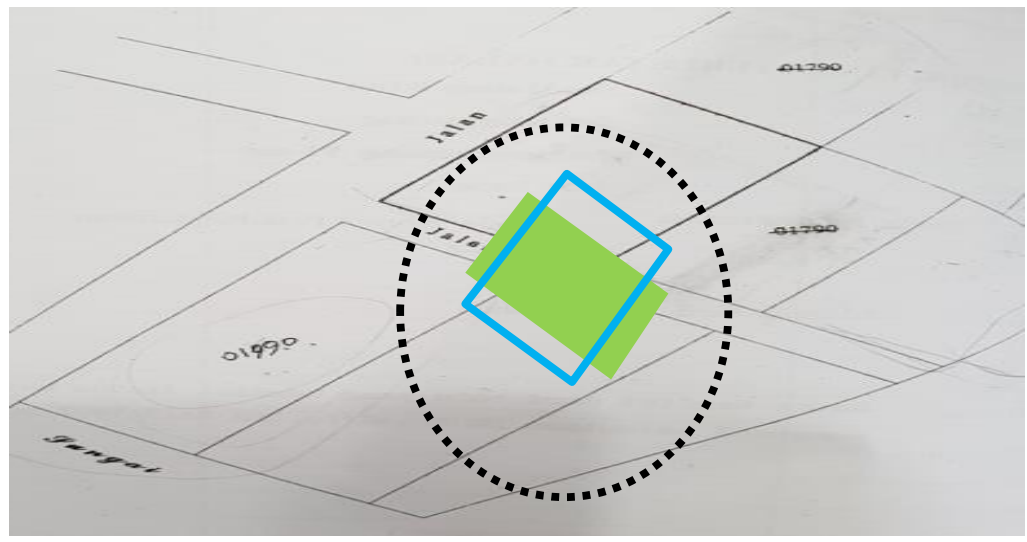

Gambar .4.10. Hasil Observasi 9 (Pemutihan Rumah Tinggal an. Corina Susantie)

Pada Gambar 4.9 terdapat sket tanah pada sertifikat dan gambar siteplan dari pemutihan rumah tinggal. Setelah digabungkan kedua gambar tersebut terdapat perbedaan bentuk tanah. Bagian berwarna biru merupakan bentuk tanah pada sertifikat sedangkan bagian berwarna hijau merupakan bentuk tanah yang sekarang telah terbangun rumah tinggal. 


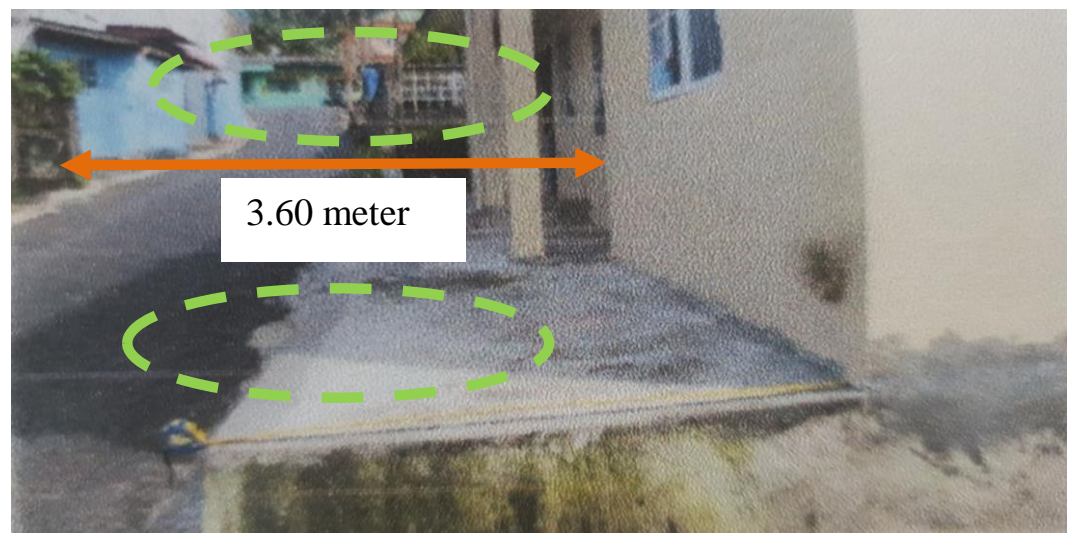

\section{Gambar 4.11. Hasil Observasi 10 (Pemutihan Rumah Tinggal an. Eka} Kurniadi)

Gambar tersebut diambil pada tanggal 7 Desember 2017 di Jl. Brigjen Katamso Gg. Kenanga III Tanjung Unggat Kota Tanjungpinang, bangunan rumah tinggal milik Eka Kurniadi hanya memiliki Garis Sempadan Bangunan 3,60 meter dari yang direkomendasikan berjarak 6,00 meter. Ruang Terbuka Hijau (RTH) minimal $10 \%$ pada lokasi bangunan tidak dipenuhi oleh pemilik bangunan, seluruh sisa lahan pada sisi bangunan di semen sehingga tidak terdapat penghijauan.
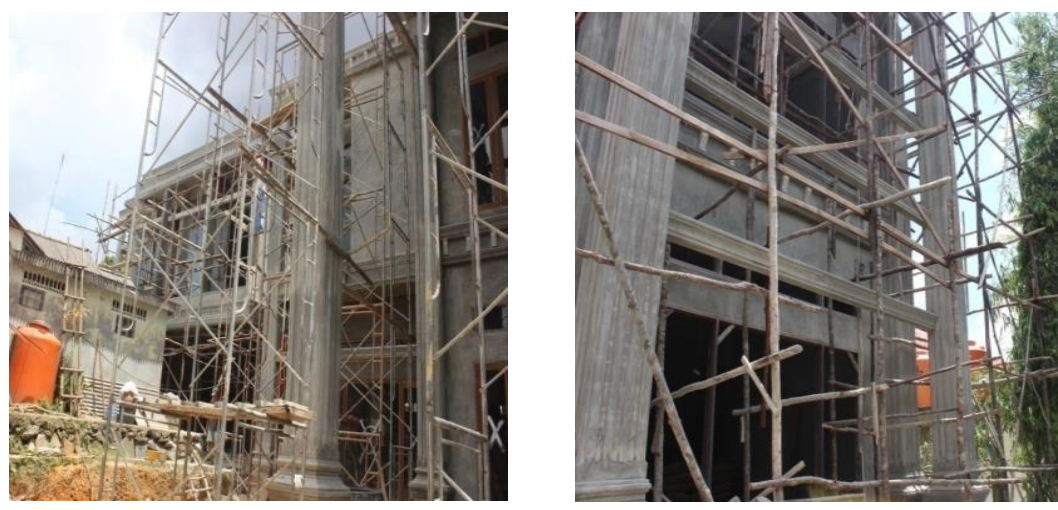

Gambar .4.12. Hasil Observasi 11 (Pembangunan Rumah Tinggal an. Hartati)

Gambar tersebut diambil pada tanggal 7 Desember 2017 di Jl. Merpati Kota Tanjungpinang, pembangunan rumah tinggal telah berjalan sebelum memiliki Izin Mendirikan Bangunan.Namun setelah peneliti berikan pemahaman akan 
arti pentingnya izin mendirikan bangunan maka yang bersangkutan berjanji akan mengurus izin bangunan rumah tinggalnya.

Dari Penelitian dilapangan terkait pembangunan rumah tinggal dapat dikatakan bahwa kepatuhan masyarakat terhadap Peraturan Daerah Kota Tanjungpinang Nomor 7 Tahun 2010 Tentang Bangunan Gedung Terkait Izin Mendirikan Bangunan Rumah Tinggal di Kota Tanjungpinang sangat rendah. Oleh karena itu peraturan-peraturan hukum dalam pelaksanaannya tidak berjalan dengan sendirinya, akan tetapi harus didukung oleh beberapa factor yang mempengaruhi efektifitas hukum itu sendiri ( Soeryono Soekanto).

Upaya penerapan peraturan-peraturan daerah kemasyarakat tidak selalu berjalan dengan mulus, akan tetapi banyak kendala dan hambatan yang di hadapi. Demikian halnya dengan penerapan Perda tersebut diatas, agar penerapan peraturan -peraturan tersebut dapat berjalan dengan baik dan maksimal, maka penulis menyarankan solusi diantaranya adalah :

1. Adanya sosialisasi

Setiap Intansi terkait, harus dapat memberikan sosialisasi yang baik dan benar serta tepat waktu dan sasaran kepada masyarakat menyangkut tata cara pengurusan izin, persyaratan izin, SOP, aturan teknis dan administrasi yang harus di penuhi dan sanksi yang diterima, sehingga masyarakat akan memahami dan menyadari akan arti pentingnya IMB.

2. Pengawasan

Upaya tindakan pengawasan bagi penyelenggara bangunan gedung harus dilakukan secara berkala dan kontinyu. Pemantauan dilapangan harus sering dilakukan baik yang memiliki IMB maupun yang belum ada IMBnya sehingga apabila ada hal-hal yang tidak sesuai aturan dapat segera diketahui dan diberikan teguran .

3. Penertiban

Penertiban adalah merupakan upaya tindakan penegakan hukum sesuai dengan peraturan perundangan yang berlaku. Langkah Penertiban harus segera dilakukan apabila dilapangan ditemukan suatu pelanggaran, ketidaksesuaian dan penyimpangan terhadap komitmen ataupun aturan yang berlaku.

4. Penindakan dan sanksi yang tegas.

Upaya penindakan dan sanksi yang tegas ini sangat perlu dilakukan untuk memberikan efek jera bagi para pelanggarnya. Sistem kompromi dan tolerasi harus dihilangkan, sehingga masyarakat akan takut dan lambat laun akan menyadari akan pentingnya suatu aturan. Namun demikian proses penindakan dan sanksi arus sesuai dengan tahapan dan sesuai dengan Peraturan Daerah Kota Tanjungpinang Nomor 7 Tahun 2010. Demikian halnya upaya penindakan dan sanksi yang tegas juga harus diterapkan bagi para Aparatur Pemerintah yang tidak dapat disiplin menjalankan tugas dan kewajibannya dengan baik dan benar. 
5. Sarana dan prasarana pendukung penegak Perda.

Kelengkapan alat, sumberdaya manusia dan financial akan mempengaruhi proses eksekusi dan penegakan Peraturan Daerah. Untuk itu sarana dan prasarana pendukung harus tersedia supaya memberikan hasil yang maksimal dalam melaksanakan pekerjaannya.

\section{Kesimpulan}

Berdasarkan uraian tersebut diatas, maka dapat diambil suatu kesimpulan sebagai berikut :

1. Implementasi Peraturan Daerah Kota Tanjungpinang Nomor 7 Tahun 2010 tentang Bangunan Gedung Terkait Izin Mendirikan Bangunan Rumah Tinggal di Kota Tanjungpinang sudah berjalan akan tetapi belum efektif secara maksimal. Hal ini bisa dilihat dari data yang ada di DPMPTSP dari tahun 2009 hingga 2017 hanya terdapat 11.870 unit rumah tinggal yang memiliki IMB. Peran Pemerintah dalam hal ini Dinas PU dan Tata Ruang, Dinas Lingkungan Hidup dan DPMPTSP sudah melaksanakan tugasnya sesuai dengan TUPOKSI akan tetapi belum maksimal terutama terkait pemberian sosialisasi dan pengawasan tentang Perda Bangunan Gedung ke Masyarakat. Demikian halnya dengan Satpol PP sebagai penegak Perda, kurangnya disiplin dalam menjalankan tugas dan kewajibannya, diantaranya kurangnya ketegasan dalam memberikan penertiban dan sanksi yang diberikan serta keterbatasan sarana dan prasarana pendukung menjadikan titik lemah dalam penegakan aturan dan membuat masyarakat kurang pro aktif dengan aturan tersebut.

2. Lemahnya pengawasan dan penindakan, serta sanksi yang tegas bagi para Aparatur Pemerintah yang melanggar aturan dan tidak dapat disiplin menjalankan tugas dan kewajibannya dengan baik dan benar, sehingga akan berpengaruh terhadap Efektifitas Perda Nomor 7 Tahun 2010. 


\section{DAFTAR PUSTAKA}

\section{Buku buku}

Abdul Kadir Ahmad., Dasar-dasar Metodologi Penelitian Kualitatif, Makasar: Indobis Media Centre, 2003.

Amirudin dan Zainal Asikin, Pengantar Metode Penelitian Hukum, Jakarta: Rajawali Press, 2003.

Hans Kelsen, Teori Hukum Murni, Bandung: Nusa Media, Juni 2016.

Soerjono Soekanto, Efektifitas Hukum dan Penerapan Sanksi, Bandung: CV. Ramadja Karya, 1988.

Soerjono Soekanto, Faktor-Faktor yang Mempengaruhi Penegakan Hukum, Jakarta: PT Raja Grafindo Persada 2005.

Soerjono Soekanto, Pengantar Penelitian Hukum, Jakarta: Rajawali Pers,1996.

Sri Pudiatmo, Perizinan Problem dan Upaya Pembenahan, Bandung: Rezki Press, 2007.

\section{Internet}

Kamus Besar Bahasa Indonesia Online, http://kbbi.web.id/efektif, diakses tanggal, 3 November 2017.

\section{Peraturan Perundang-Undangan}

Undang-Undang Nomor 28 Tahun 2002 Tentang Bangunan Gedung.

Undang-Undang Nomor 1 Tahun 2011 Tentang Perumahan dan Kawasan Permukiman

Peraturan Pemerintah Republik Indonesia Nomor 36 Tahun 2005 Tentang Peraturan Pelaksanaan Undang-undang Nomor 28 Tahun 2002 Tentang Bangunan Gedung.

Peraturan Pemerintah Republik Indonesia Nomor 53 Tahun 2010 Tentang Disiplin Pegawai Negeri Sipil.

Peraturan Menteri Dalam Negeri Nomor 32 Tahun 2010 Tentang Pedoman Pemberian IMB. 
Peraturan Menteri Pekerjaan Umum dan Perumahan Rakyat Nomor 5 Tahun $2016 .$.

Peraturan Daerah Kota Tanjungpinang Nomor 7 Tahun 2010 Tentang Bangunan Gedung.

Peraturan Daerah Kota Tanjungpinang Nomor 7 Tahun 2012 Tentang Retribusi Perizinan Tertentu.

Peraturan Daerah Kota Tanjungpinang Nomor 10 Tahun 2014 Tentang RTRW

Data Badan Pusat Statistik Kota Tanjungpinang Tahun 2017.

Data DPMPTSP Kota Tanjungpinang 2017. 